\title{
PENERAPAN PENDEKATAN MATEMATIKA REALISTIK TERHADAP KEMAMPUAN PEMECAHAN MASALAH
}

\author{
Hafsah Puspita Dewi ${ }^{1}$, Elsa Fitri ${ }^{2}$,Eva Dwi Minarti ${ }^{3}$ \\ Pendidikan Matematika FPMS-IKIP Siliwangi \\ 1'hafsahpuspitadewi@gmail.com, ${ }^{2}$ elsafitriw@gmail.com, ${ }^{3}$ eva.arti@yahoo.co.id \\ Diterima: XXXXX X, XXXX; Disetujui: XXXXX X, XXXX
}

\begin{abstract}
This study aims to know the achievement of the ability of the solution of the problems a useful or valuable junior high school students who used the realisticmathematics conventional by learning, the experimental work on this, matter used arithmetic is social class VII junior high school semester the even. Methods used is quantitative, who is in the form of experiments in supported by data from pretes and postes.The population research is junior high school students class VII in west bandung.With 43 sample graders experiment and 40 graders controls on the academic year 2017 / 2018. An instrument that is used is math tests the ability of the solution of the problems .Processing the data were analyzed using ibm spss version 21 application statistics . Processing data using analysis test normality and has been continued by test the average namely mann-whitney test .Based on the analysis conducted, results showed that the achievement of the ability of the solution of the problems a useful or valuable junior high school students who used the mathematics realistic better than conventional learning .
\end{abstract}

Keyword: math problem solving, realistic approach mathematics.

\begin{abstract}
Abstrak
Penelitian ini bertujuan untuk mengetahui pencapaian kemampuan pemecahan masalah matematik siswa SMP yang menggunakan pendekatan matematika realistik dengan pembelajaran konvensional, pada penelitian ini, materi yang digunakan adalah Aritmatika Sosial kelas VII SMP semester genap. Metode yang digunakan adalah kuantitatif, yang dilakukan dalam bentuk eksperimen di dukung dengan data hasil dari pretes dan postes. Populasi penelitian ini adalah siswa SMP kelas VII di Bandung Barat. Dengan sampel 43 siswa kelas eksperimen dan 40 siswa kelas kontrol pada tahun ajaran 2017/2018. Instrumen yang digunakan adalah tes kemampuan pemecahan masalah matematik. Pengolahan data tersebut dianalisis dengan menggunakan aplikasi IBM SPSS Statistik Versi 21. Pengolahan analisis data menggunakan uji normalitas dan dilanjutkan dengan uji rata-rata yaitu uji mann-whitney. Berdasarkan analisis yang telah dilakukan, diperoleh bahwa pencapaian kemampuan pemecahan masalah matematik siswa SMP yang menggunakan pendekatan matematika realistik lebih baik daripada pembelajaran konvensional.
\end{abstract}

Kata Kunci: pemecahan masalah matematik, pendekatan matematika realistik.

Cara Mengutip: Dewi, H. P., Fitri, E., \& Minarti, E. D., (2018). Penerapan Pendekatan Matematika Realistik terhadap Kemampuan Pemecahan Masalah. JPMI - Jurnal Pembelajaran Matematika Inovatif, 1 (5), 949-956.

\section{PENDAHULUAN}

Tidak dipungkiri matematika sampai saat ini menjadi pelajaran yang mempunyai tingkat kesulitan belajar paling banyak yang di alami siswa, terlebih lagi salah satu dari kesulitan siswa adalah kurangnya suatu pemahaman dan ketertarikan siswa dalam pembelajaran matematika. Hal ini sependapat dengan hasil analisis yang dilakukan(Putra et al., 2018) 
terhadap salah satu sekolah menengah di Bandung Barat yang mengemukakan bahwa dari 35 siswa dalam satu kelas hanya 14,29\% siswa yang sudah berada pada tahap berpikir formal (abstrak). Kondisi tersebut menyebabkan sebagian besar siswa belum dapat memahami konsep matematika yang abstrak apalagi untuk diterapkan dalam penyelesaian masalah.

Pemecahan masalah menurut Anggraeni \& Herdiman (2018) merupakan suatu proses memecah atau menyelesaikan suatu persoalan dengan menggunakan prosedur-prosedur untuk menuju kepada penyelesaian yang diharapkan. Menurut Aripin (Alifah \& Aripin, 2018) menerangkan bahwa berpikir merupakan sebuah tindakan yang tidak gegabah dalam menyelesaikan suatu masalah serta menggunakan akal rasional dalam menentukan keputusan. Sedangkan menurut Hidayat \& Sariningsih (2018) mengatakan bahwa dalam pembelajaran matematika pemecahan masalah merupakan inti pembelajaran yang merupakan kemampuan dasar dalam proses pembelajaran. Sesuai dengan penelitian tersebut salah satu penyelesaian dari suatu masalah disebut dengan pemecahan masalah. Suatu masalah biasanya memuat situasi yang mendorong seseorang tersebut untuk menyelasaikannya namun tidak secara langsung dapat mengetahui apa harus dikerjakan untuk menyelesaikan masalah tersebut. Jika diberikan suatu masalah terhadap seorang anak kemudian anak tersebut sudah mengetahui bagaimana penyelesaian yang dapat dilakukan dengan benar, maka persoal tersebut belum dapat dinyatakan sebagai masalah. Sebuah persoalan dapat dikatakan sebagai suatu masalah tergantung kepada orang yang menghadapi masalah tersebut dan tergangtung kepada karakteristik masalahnya.

Berdasarkan BNSP (Kusumawati \& Irwanto, 2016) menyatakan bahwa mata pelajaran matematika bertujuan agar kemampuan memecahkan masalah yang dimilikisiswameliputi kemampuan memahami masalah, merancang suatumodel matematika, menyelesaikan soal, serta menafsirkan hasil yang diperoleh, maka dapat terlihat suatu pembelajaran matematika adalah kemampuan pemecahan masalah, kemampuan penalaran, dan kemampuan komunikasi matematika. Sehubungan dengan pernyataan tersebut Depdiknas (Kusumawati \& Irwanto, 2016) hal yang serupa bahwa tujuan dari mata pelajaran matematika yaitu agar kemampuan memecahkan masalah yang dimiliki siswa meliputi kemampuan memahami masalah, merancang dan menyelesaikan model matematika, serta menafsirkan solusi yang telah diperoleh.

Menurut Sugandi (2011) suatu kemampuan pemecahan masalah yang penting dalam sebuah pendidikan matematika dilihat dari tujuan-tujuan pembelajaran matematika dalam KTSP. Disamping hal tersebut kemampuan pemecahan masalah perlu dikembangkan, berkaitan dengan pendapat NCTM (Sugandi, 2011) bahwa salah satu fokus dari pembelajaran matematika adalah kemampuan pemecahan masalah. Selain itu yang menjadi alasan untuk mempelajari matematika dengan kemampuan pemecahan masalah tidak hanya untuk memecahkan masalah saja melainkan ada pula suatu kontek dimana konsep serta kecakapan dapat dipelajari. Adapun indikator menurut Polya (Hadi \& Radiatul, 2014) ada 4 yaitu: (1) memahami masalah, (2) menentukan rencana strategi pemecahan masalah, (3) melakukan perhitungan, dan (4) memeriksa kembalihasil jawaban.

Untuk mencapai tujuan tersebut, maka diperlukan sebuah proses pembelajaran yang mampu berupaya agar tercapainya kemampuan pemecahan masalah matematik siswa. Menurut Polya (Ruhyana, 2016) pemecahan masalah merupakan suatu usaha dalam mencari solusi dari sulitnya permasalahan yang dihadapi guna mencapai suatu tujuan yang tidak mudah utuk dicapai dengan segera. Pemecahan masalah matematik merupakan suatu proses menemukan jawaban dalam persoalan yang bervarisi serta berhubungan denan kehidupan sehari-hari. 
Pemecahan masalah dapat dikatakan sebagai kemampuanberpikir tingkat tinggi suatu proses menerima masalah serta usaha dalam menyelesaikannya. Hal ini dikarenakan siswa akan memperoleh pengalaman dalam mengemukakan apa yang diketahui dan kekreatifan yang dimilikinya untuk menyelesaikan soal yang tidak biasa diberikan oleh guru. Penjelasan tersebut bersesuaian dengan pernyataan yang dikemukakan oleh Susanto (Kusumawati \& Irwanto, 2016) bahwa pemecahan masalah ialah proses menerapkan pengetahuan siswa sebelumnya terhadap situasi yang baru. Serta pemecahan maslaah merupakan aktivitas yang harus dilakukan pada pembelajaran matematika, dikarenakan tujuan dari pembelajaran yang ingin dicapai dalam pemecahan masalah adalah berkaitan dengan kehidupan sehari-hari, hal ini sejalan dengan pendekatan matematika realistik (PMR).

Pendekatan matematika realistik adalah salah satu pendekatan yang menekankan matematika pada pengajaran bermakna yang dikaitkan dengan kehidupannya atau sehari-hari yang bersifat realistik. Setelah itu siswa yang mampu menyelesaikan suatu masalahnya dengan menggunakan konsep yang telah diperolehnya atau siswa tersebut dapat menyelesaikan masalahnya dengan cara mengubahnya ke model matematika terlebih dahulu. Melalui kegiatan pembelajaran pendekatan matematika realistik siswa dapat mengembangkan kemampuan pemecahan masalah dan diharapkan siswa termotivasi untuk menyelesaikan pertanyaan soal-soal yang mengarahkan siswa dalam proses pemecahan masalah. Oleh karena itu pemecahan masalah dapat dikatakan sebagai salah satu upaya mencari solusi dari kesulitan yang dihadapi dan mencapai suatu tujan yang tidak mudah untuk segera dicapai. Dengan demikian pemecahan masalah termasuk pada salah satu pembelajaran yang mampu menciptakan ide baru yang menggunkan aturan yang telah dipelajari.

Sehubungan dengan hal tersebut, menurut Yuspriati, Minarti, \& Rohmah (2015) bahwa pendekatan matematika yang merupakan adapatasi dari Realistic Mathematics Education (RME) ini merupakan pendekatan yang dikembangan oleh Hans Freudenthal di Belanda sejak tahun 1970-an. Teori pembelajaran pendidikan matematika realistik berhubungan dengan kenyataannyaatau pernah dialami siswa, menekankan terhadap keterampilan dalam proses, saling bertukar pendapat serta mengemukakan pendapat dengan teman sekelas sehingga terciptanya suatu kondisi dimana mereka dapat menemukan sendiri (student centered) atau bisa di katakan sebagai kebalikan dari pembelajaran terpusat pada guru (teacher centered) dengan demikian matematika kegunaanya untuk menyelesaikan masalah individu ataupun kelompok dalam kehidupan sehari-hari. Adapun karakteristik pendidikan matematika realistik yang terdiri dari lima karakteristik yaitu: (1) penggunaan "kontek nyata" (2) penggunaan "model" (3) pengaitan dalam dan antar topik matematika; (4) penggunaan metode interaktif dan (5) menghargai variasi jawaban dan kontribusi siswa Syahputra (2013).

Berdasarkan uraian diatas, maka tujuan peneliti adalah mengetahui upaya pencapaian kemampuan pemecahan masalah mtematik siswa SMP dengan menggunakan pendekatan matematika realistik.

\section{METODE}

Metode pada penelitian ini yaitu kuantitatif dilakukan dalam bentuk kuasi eksperimen menurut Effendi (2012) yang didukung dengan data hasil dari tes awal dan tes akhir. Penelitian kuantitatif ini adalah untuk melihat perbandingan antara kemampuan pemecahan masalah matematik siswa yang menggunakan pendekatan matematika realistik dengan pembelajaran konvensional. Data tersebut diperoleh untuk melihat tercapai atau tidaknya 
kemampuan pemecahan masalah matematik siswa. Dengan populasi siswa kelas VII SMP yang berada di wilayah Bandung Barat. Sampel diambil dari salah satu kelas yang terdiri dari 43 siswa kelas eksperimen dan 40 siswa kelas kontrol pada tahun ajaran 2017/2018. Pengolahan data tersebut dianalisis dengan menggunakan aplikasi IBM SPSS Statistik Versi 21. Rubrik penskoran kemampuan tersebut dinilai berdasarkan pada indikator. Berikut rubrik penskoran menurut Sumarmo (Muliati, 2017) untuk setiap soal:

Tabel 1. Rubrik Penskoran Kemampuan Pemecahan Masalah Matematik

\begin{tabular}{|c|c|c|}
\hline Aspek yang dinilai & Skor & Keterangan \\
\hline \multirow{3}{*}{ Memahami masalah } & 0 & Tidak ada jawaban sama sekali \\
\hline & 1 & $\begin{array}{l}\text { Salah mengartikan sebagian soal atau mengabaikan } \\
\text { kondisi soal }\end{array}$ \\
\hline & 2 & Memahami masalah \\
\hline \multirow{4}{*}{$\begin{array}{c}\text { Menentukan rencana } \\
\text { strategi pemecahan } \\
\text { masalah }\end{array}$} & 0 & Tidak ada strategi sama sekali \\
\hline & 1 & $\begin{array}{l}\text { Menggunakan strategi yang tidaktepat dan tidak } \\
\text { dapat dilanjutkan }\end{array}$ \\
\hline & 2 & $\begin{array}{l}\text { Menggunakan strategi yang benar } \\
\text { tetapijawabansalah }\end{array}$ \\
\hline & 3 & $\begin{array}{l}\text { Menggunakan beberapa prosedur yang } \\
\text { menggunakanstrategi }\end{array}$ \\
\hline \multirow{4}{*}{$\begin{array}{l}\text { Melakukan } \\
\text { perhitungan }\end{array}$} & 0 & Tidak ada solusi sama sekali \\
\hline & 1 & $\begin{array}{l}\text { Menggunakan beberapa prosedur yang mengarah ke } \\
\text { solusi benar }\end{array}$ \\
\hline & 2 & $\begin{array}{l}\text { Hasil atau sebagian hasil salah tetapi hanya salah } \\
\text { perhitungan saja }\end{array}$ \\
\hline & 3 & Dapatmelakukanperhitungandanbenar \\
\hline \multirow{3}{*}{$\begin{array}{c}\text { Memeriksa kembali } \\
\text { jawaban yang } \\
\text { diperoleh }\end{array}$} & 0 & $\begin{array}{l}\text { Tidak dapatmemeriksakembali atau tidak } \\
\text { diberiketerangan }\end{array}$ \\
\hline & 1 & Tidaksampaipadatahpmemeriksakembalijawaban \\
\hline & 2 & $\begin{array}{l}\text { Pemeriksaan dilaaksanakan untuk melihat } \\
\text { keterangan hasil dan proses }\end{array}$ \\
\hline
\end{tabular}

\section{HASIL DAN PEMBAHASAN}

\section{Hasil}

Untuk melihat adanya perbedaan kemampuan pemecahan masalah matematik antara kedua kelas dilakukan pengujian hasil tes kemampuan tersebut dengan melakukan pretes (tesawal) dan postes (tesakhir). Berikut hasil dari uji statistik yang telah diperoleh:

a. Data Pretes

Tes awal diadakan untuk melihat kemampuan awal siswa sebelum proses pembelajaran berlangsung dan untuk mengetahui kesetaraan sampel. Hasil dari analisis data tersebut disajikan pada tabel berikut: 
Tabel 2. Hasil Uji Normalitas Data Pretes

\section{Kelas Shapiro-Wilk}

\begin{tabular}{llrrr}
\cline { 3 - 5 } Pretes & & Statistic & df & \multicolumn{1}{c}{ Sig. } \\
& Eksperimen & .908 & 43 & .002 \\
& Kontrol & .911 & 39 & .005 \\
\hline
\end{tabular}

Berdasarkan hasiltersebut, terlihat bahwa siswa yang akan memperoleh pembelajaran menggunakan pendekatan realistik matematik dan pembelajaran konvensional diperoleh nilai Sig. $<0,05$. Sesuai dengan hipotesis apabila Sig. $<0,05$ maka $\mathrm{H}_{\mathrm{o}}$ ditolak. Dengan demikian kedua data sampel tersebut tidak berdistribusi normal, maka dilanjutkan dengan pengujian dua rata-rata dengan uji Mann-Whitney.

Tabel 3. Hasil Uji Mann-Whitney Data Pretes

Pretes

\begin{tabular}{lr}
\hline Mann-Whitney U & 818.500 \\
Wilcoxon W & 1598.500 \\
Z & -.188 \\
Asymp. Sig. (2-tailed) & .851 \\
\hline
\end{tabular}

Dari Tabel 3. Hasil uji mann-whitney terlihat bahwa nilai signifikasinya adalah 0,851 . Nilai tersebut $>0,05$ sehingga berdasarkan kriteria $\mathrm{H}_{\mathrm{o}}$ diterima. Hal ini menunjukan bahwa, siswa yang menggunakan pendekatan matematik realistik dengan yang menggunakan pembelajaran konvensional tidak mempunyai kemampuan awal yang sama.

b. Data Postes

Tes ini adalah tes akhir untukmelihat kemampuan akhir siswa sesudah proses pembelajaran berlangsung.

Tabel 4. Hasil Uji Normalitas Data Postes

\begin{tabular}{llrrr}
\hline \multirow{2}{*}{ Postes } & Kelas & \multicolumn{3}{c}{ Shapiro-Wilk } \\
\cline { 2 - 5 } & & Statistic & \multicolumn{1}{c}{ Df } & \multicolumn{1}{c}{ Sig. } \\
\cline { 2 - 5 } & Eksperimen & .962 & 43 & .163 \\
& Kontrol & .919 & 39 & .008 \\
\hline
\end{tabular}

Berdasarkan pada Tabel 4 tersebut terlihat uji normalitas dengan Shapiro-Wilk pada salah satu kelasnya memperoleh signifikan 0,008. Nilai tersebut memenuhi kriteria Sig. $\leq 0,05$ maka $H_{0}$ ditolak, yang artinya sampel tidak berdistribusi normal. Sampel menunjukan tidak berdistribusi normal oleh karena itu dilanjutkan dengan dengan uji perbedaan dua rata-rata yaitu non-parametrik dengan Mann-Whitney. Dengan hasil yang diperoleh pada tabel berikut.

Tabel 5. Hasil Uji Mann-Whitney

\section{Postes}

\begin{tabular}{lr}
\hline Mann-Whitney U & 302.000 \\
Wilcoxon W & 1082.000 \\
Z & -4.989 \\
Asymp. Sig. (2-tailed) & .000 \\
\hline
\end{tabular}


Berdasarkan hasil tersebut nilai signifikasinya yaitu 0,000 . Nilai tersebut memenuhi Sig. $\leq$ 0,05 maka berarti bahwa pencapaian kemampuan pemecahan masalah matematik siswa yang pembelajarannya menggunakan pendekatan realistik matematik lebih baik daripada yang menggunakan pembelajaran kovensional.

\section{Pembahasan}

Setelah hasil data pretes dan postes terkumpul selanjutnya dilakukan analisis data pretes dan postes. Untuk melihat pencapaian kemampuan pemecahan masalah matematik siswa yang menggunakan pendekatan matematika realistik dengan pembelajaran konvensional. Berdasarkan hasil dari pretes (data awal) ternyata data tidak berdistribusi normal hal ini ditunjukan nilai signifikasi kelas eksperimen adalah 0,002 dan nilai signifikasi kelas kontrol 0,004 makanilaitersebut $<$ dari signifikasi 0,05. Data tidak berdistribusi normal maka dilakukan analisis uji mann-whitney, hasil perhitungan uji mann-whitney terlihat bahwa nilai signfikasinya adalah 0,851 nilai tersebut kurang dari Sig 0,05 yang berarti $\mathrm{H}_{\mathrm{o}}$ diterima. Hal ini menunjukan tidak terdapat perbedaan antara siswa yang menggunakan pendekatan matematika realistik dengan pembelajaran konvensional. Sejalan dengan hasil analisis yang dilakukan oleh Anisa (2014) di Kota Garut bahwa tingkat penguasaan kemampuan pemecahan masalah matematik siswa dilihat dari pretes menunjukan bahwa kelas ekperimen termasuk kedalam kategori kurang. Hal tersebut menunjukan bahwa sebelum dilakukannya perlakuan pembelajaran menggunakan pendekatan matematika realistik, tingkat kemampuan siswa tersebut rendah. Menurut Nataliasari (2013) agar kesulitan yang dihadapi siswa dapat ditingkatkan tentu dibutuhkan suatu pendekatan pembelajaran yang inovatif bagi siswa. Suatupendekatan yang dapat memberikan inovasi untuk permasalahan diatas adalah pendekatan matematika realistik.

Apabila dilihat dari hasil analisis postes untuk melihat pencapaian kemampuan pemecahan masalah matematik siswa yang menggunakan pendekatan matematika realistik dengan pembelajaran konvensional ternyata menunjukan bahwa kelas ekperimen yang lebih baik. Hal ini dibuktikan dari hasil data di atas yaitu untuk kelas eksperimen nilai signifikasi 0,163 dan nilai signifikasi untuk kelas kontrol 0,008. Diambil dari salah satu kelas menunjukan bahwa nilai signifikasinya kurang dari $P$-Value 0,05 maka dinyatakan $\mathrm{H}_{\mathrm{o}}$ ditolak, maka data tidak berdistribusi normal.Analisis selanjutnya adalah dengan pengujian non parametrik mannwhitney. Dilihat dari hasil, maka analisis yang dapat dituliskan nilai signifikasinya yaitu 0,000 hal ini menunjukan Signifikasi <0,05 sehingga pencapaian kemampuan pemecahan masalah matematik siswa yang pembelajarannya yang menggunakan pendekatan matematika realistik lebih baik daripada pembelajaran konvensional. Sejalan pula dengan hasil penelitian yang dilakukan oleh Muchlis (2012) di Kota Padang, yang menunjukan kemampuan pemecahan masalah matematik siswa yang belajar dengan pendekatan matematika realistik lebih baik daripada siswa yang belajar dengan pendekatan konvensional. Hal tersebut membuktikan bahwa setelah pembelajaran menggukan pendekatan matematika realistik, kemampuan pemecahan masalah matematik siswa akan lebih baik.

\section{KESIMPULAN}

Simpulan yang dapat diambil dari hasil penelitian ini adalah terdapat hubungan yang baik dan signifikan antara kemampuan pemecahan masalah matematik dengan pendekatan matematika realistik bahwa pencapaian kemampuan pemecahan masalah matematik siswa yang menggunakan pendekatan matematik realistik lebih baik daripada yang menggunakan pembelajaran konvensional. Perkembangan kemampuan pemecahan masalah matematik terlihat dari hasil jawaban siswa yang sudah mencapai indikator yang diharapkan. Oleh karena itu pembelajaran matematika realistik dapat dijadikan sebagai alternatif dalam pembelajaran 
matematika untuk memberikan pengalaman dan suasana pembelajaran yang beragam bagi peserta didik. Dan memberikan kontribusi yang baik bagi peningkatan kemampuan pemecahan masalah matematik. Hal tersebut dapat dijadikan sebagai salah satu cara untuk mencapai tujuan dari kemampuan pemecahan masalah. Untuk meningkatkan kemampuan pemecahan masalah matematik perlu dikembangkan keterampilan memahami masalah, membuat model matematika, menyelesaikan dan menafsirkan solusinya.

\section{UCAPAN TERIMA KASIH}

Puji dan syukur kepada Allah SWT, atas segala berkat dan karunianya yang telah dilimpahkan, sehingga penulis dapat menyelesaikan penyusunan artikel ini.Terwujudnya artikel ini adalah berkat bantuan berbagai belah pihak yang telah mendorong dan membimbing penulis,baik tenaga, ide-ide, maupun pemikiran. Olehkarena itu dalam kesempatan ini penulis ingin mengucapkan terimakasih yang sebesar-besarnya kepada dosen pembimbing dan kampus IKIP Siliwangi.

\section{DAFTAR PUSTAKA}

Anggraeni, R., \& Herdiman, I. (2018). KEMAMPUAN PEMECAHAN MASALAH MATEMATIK SISWA SMP PADA MATERI LINGKARAN BERBENTUK SOAL KONTEKSTUAL DITINJAU DARI GENDER. Jurnal Numeracy, 5(1).

Anisa, W. N. (2014). Peningkatan Kemampuan Pemecahan Masalah Dan Komunikasi Matematik Melalui Pembelajaran Pendidikan Matematika Realistik Untuk Siswa SMP Negeri Di Kabupaten Garut, 1(1).

Alifah, N., \& Aripin, U. (2018). Proses Berpikir Siswa SMP dalam Memecahkan Masalah Matematik Ditinjau dari Gaya Kognitif Field Dependent dan Field Independent. JPMI (Jurnal Pembelajaran Matematika Inovatif), 1(4).

Effendi, L. A. (2012). Pembelajaran Matematika dengan Metode Penemuan Terbimbing untuk Meningkatkan Kemampuan Representasi dan Pemecahan Masalah Matematis Siswa SMP. Penelitian Pendidikan, 13, 1-10.

Hadi, S., \& Radiatul. (2014). METODE PEMECAHAN MASALAH MENURUT POLYA UNTUK MENGEMBANGKAN DI SEKOLAH MENENGAH PERTAMA Sutarto Hadi , Radiyatul, 2, 53-61.

Hidayat, W., \& Sariningsih, R. (2018). Kemampuan Pemecahan Masalah Matematis dan Adversity Quotient Siswa SMP Melalui Pembelajaran Open Ended. JNPM (Jurnal Nasional Pendidikan Matematika), 2(1), 109-118.

Kusumawati, E., \& Irwanto, R. A. (2016). Penerapan Metode Pembelajaran Drill untuk Meningkatkan Kemampuan Pemecahan Masalah Matematis Siswa Kelas VIII SMP, 4(April), 49-57.

Muchlis, E. E. (2012). PENGARUH PENDEKATAN PENDIDIKAN MATEMATIKA REALISTIK INDONESIA ( PMRI ) TERHADAP PERKEMBANGAN KEMAMPUAN 
PEMECAHAN MASALAH SISWA KELAS II SD KARTIKA 1 . 10 PADANG, $X(2)$, $136-139$.

Muliati, T. (2017). Meningkatkan Kemampuan Pemahaman Dan Pemecahan Masalah Serta Disposisi Matematik Siswa SMP Melalui Pendekatan Kontekstual. Tesis STKIP Siliwangi Bandung.

Nataliasari, I. (2013). PENGGUNAAN MODEL PEMBELAJARAN KOOPERATIF TIPE THINK PAIR SHARE (TPS) UNTUK MENINGKATKAN KEMAMPUAN PENALARAN DAN PEMECAHAN MASALAH MATEMATIS SISWA MTS.

Putra, H. D., Thahiram, N. F., Ganiati, M., Nuryana, D., Studi, P., Matematika, P., ... Siswa, P. (2018). Kemampuan Pemecahan Masalah Matematis Siswa SMP pada Materi Bangun Ruang, 6(2), 82-90.

Ruhyana. (2016). ANALISIS KESULITAN SISWA DALAM PEMECAHAN, 10(2), 106118.

Sugandi, A. I. (2011). PENGARUH PEMBELAJARAN BERBASIS MASALAH DENGAN SETTING KOOPERATIF JIGSAW TERHADAP KEMAMPUAN PEMECAHAN MASALAH DAN KOMUNIKASI MATEMATIS, 171-180.

Syahputra, E. (2013). PENINGKATAN KEMAMPUAN SPASIAL SISWA MELALUI PENERAPAN PEMBELAJARAN MATEMATIKA REALISTIK Edi. Cakrawala Pendidikan, No. 3, 353-364.

Yuspriati, D. N., Minarti, E. D., \& Rohmah, M. S. (2015). Analisis Penerapan Pembelajaran Matematika Berbasis PMRI pada Kelas I Sekolah Dasar di Kota Bandung. Jurnal Ilmiah UPT P2M STKIP Siliwangi, 2(1), 1. 